University of Louisville

ThinkIR: The University of Louisville's Institutional Repository

College of Arts \& Sciences Senior Honors

Theses

College of Arts \& Sciences

$5-2015$

\title{
A new tradition : understanding Othello through the performance of Emilia.
}

Megg Ward

University of Louisville

Follow this and additional works at: https://ir.library.louisville.edu/honors

Part of the Dramatic Literature, Criticism and Theory Commons

\section{Recommended Citation}

Ward, Megg, "A new tradition : understanding Othello through the performance of Emilia." (2015). College of Arts \& Sciences Senior Honors Theses. Paper 30.

http://doi.org/10.18297/honors/30

This Senior Honors Thesis is brought to you for free and open access by the College of Arts \& Sciences at ThinkIR: The University of Louisville's Institutional Repository. It has been accepted for inclusion in College of Arts \& Sciences Senior Honors Theses by an authorized administrator of ThinkIR: The University of Louisville's Institutional Repository. This title appears here courtesy of the author, who has retained all other copyrights. For more information, please contact thinkir@louisville.edu. 
A New Tradition: Understanding Othello Through the Performance of Emilia

\author{
By \\ Megg Ward \\ Submitted in partial fulfillment of the requirements \\ for Graduation summa cum laude \\ and \\ for Graduation with Honors from the Department of Theatre Arts \\ University of Louisville
}

May, 2015 
Introduction ............. 2-3

Part I: The Scholarship.......... 4-21

Emilia in the Text........ 4-5

Epistemological Role..... 6-7

Dramatic Locus........... 7-9

Heroism and Tragedy...... 9-12

Emilia's Age..............12-16

Previous Emilias...........16-21

Part II: My Performance......................21-39

U of L's Othello......................21-25

Crafting Emilia's Likeability...........25-31

Defining Dynamic Character Arc.....31-35

External Challenges...................35-36

Audience Response...................36-39

Conclusion.............39-40

Appendix................40-43

Bibliography............43-46 


\section{Introduction:}

In the 2004 movie, Stage Beauty, Billy Crudup stars as Edward Kynaston, one of the last great female impersonators before the parliamentary prohibition of males playing females put in place by Charles II. The movie portrays his performance of Desdemona in Othello as so affecting that it stole the show every night. In the opening scene of the film, Kynaston's performance of Desdemona's death scene causes the audience to applaud so uproariously and continuously that Kynaston (as the dead Desdemona) raises a finger to quiet them, unsuccessfully. The man playing Emilia enters and is booed by the audience, who is yelling for Desdemona to come back to life. The action then cuts to the actors exiting backstage, the man playing Emilia is visibly upset and stomps off, “Emilia dies too, you know!” But no one much cares as they brush past him, even after he announces that he quits the company.

While the movie focuses on Kynaston in his defining role as Desdemona, the film also reveals something crucial about the way audiences have viewed Emilia throughout history and in modernity. Emilia’s role is so undercut by the popular mindset, and often overlooked by critics, directors, and audiences, that she is scarcely remembered in the story of Othello. However, Emilia's role in Othello is central to the action of the story, a point that can be made clearly visible by careful choices on the part of the actor. In my performance of Emilia in the University of Louisville’s February 2015 production of Othello, I strove to redefine Emilia's 'traditional' role. Engaged in applied scholarship, I synthesized scholarly criticism, which noted Emilia’s critical role in Shakespeare's text, with research of notable and iconic portrayals of Emilia; I then sought to create, in action, a dynamic performance of Emilia that showed the audience something new about the story of Othello, revealing Emilia’s role as the backbone of the tragedy. 
Very early on in the process, when asked about my thesis, I would respond that I was performing in the University's upcoming production of Othello. The other party would nod or “ohh,” in recognition of the play and then ask what part I was playing, or guess “Desdemona?” My response of, “Emilia,” garnered politely confused expressions, and more than one, “Oh, who’s she?” Since there are only three female characters in Othello, and I had always considered Emilia an important player in the story, I was a bit shocked by the lack of popular knowledge even of her existence in the story of Othello. But, As Carol Chillington Rutter, a notable Shakespearean performance scholar, remarks, it seems that "no one much cares about Emilia’s part,” (Rutter, 148).

Therefore, making Emilia memorable to a university audience and revealing her crucially important role in fullness became the crux of my thesis project. More important than my personal performance was doing justice by the character, reclaiming her position and centrality in the minds of as many audience members as I could, as well as using her centrality to redefine the story of Othello to highlight her heroism and tragedy. I am not only investigating how Emilia is represented in the text of Othello, the possibilities for her character on the page and in her speech; but I am investigating the performance process, the active decisions that must be made in actual dramatic space which define the character presented to an audience, as well as the spontaneous and necessary interactions that emerge from rehearsal with others. This creative process is not only defined by my research and acting decisions, but by the cooperative creation of the entire ensemble and creative team. 


\section{Part I: The Scholarship}

\section{Emilia in the Text:}

Shakespeare’s source material for Othello, Cinthio, describes only "the ensign” and "the ensign's wife.” The ensign's wife is a small player in the story, not influential on any particular event, although she is the only one who survives the violence and is the one who recounts the events for publication. Shakespeare expands Cinthio’s short story and gives “additional character motivation for the four principals, Othello, Iago, Desdemona, and Emilia” (Griffin, 227). Notably, Emilia remains the character who reveals and recounts the violent events, and while Cinthio had Iago steal the handkerchief directly from Desdemona, Shakespeare allots this deed to Emilia. Yet, editors tend to “brush past her” (Rutter, 148). In M. R. Ridley’s New Arden Shakespeare edition of Othello (published in 1962), he details Shakespeare's changes from Cinthio’s original story (54), but does not include Shakespeare’s drastic change to the final scene, which not only "anchors” the scene on Emilia by making her the driving force of the end of the show, but revolves “entirely around her tragic self-revelation and disclosure” (Rutter, 148). Not to mention that Shakespeare amends the tragic triangle of death from Othello-IagoDesdemona in Cinthio, to Othello-Desdemona-Emilia, and they die literally on top of one another, instead of at various points and places as in Cinthio’s story. E.A.J. Honnigman, the editor of the third Arden Edition of Othello, published in 1998, mentions Emilia only briefly in his introduction, noting that she "repays some attention” (47).

In performance, as Rutter notices, “Emilia doesn’t merit priority casting” (168). In film, such as Orson Welles’ 1952 version, Stuart Burge’s 1965 version, and Oliver Parker’s 1995 version, Emilia’s part was "habitually cut ... so drastically that what is left is a caricature" 
(Rutter, 168). This 'habitual' cutting may be a latent result of the $19^{\text {th }}$ century tendency to follow the much shorter First Folio text rather than the quarto text, which gives many more lines to Emilia and Desdemona. Denise Whalen explores the question of the difference between the two versions and why they may have come to be in her essay, "Unpinning Desdemona:"

One of the more striking differences between the quarto (1622) and the First Folio (1623) texts of Othello is in the scene (4.3) ... While F unfolds through a leisurely 112 lines that include the Willow Song, Q clips along with only 62 lines, cutting the scene by nearly half. These two versions also differ thematically. $\mathrm{F}$ presents both Desdemona and Emilia as complex characters. ... F contains a surprisingly insightful and impassioned Emilia, who defends the behavior of wives against the ill-usage they suffer at the hands of their husbands. In contrast, Q, while it retains the narrative structure of the longer $F$ scene, significantly alters the characterization of the women by presenting both as onedimensional: Desdemona as the patient Griselda and Emilia as the shallow, saucy maid. ... the cuts occur primarily in the fourth and fifth acts, with half of all missing lines in Q coming from the roles of Desdemona and Emilia, which perhaps indicates that the play was lagging near the end, that the boy actors proved uninteresting, or, finally, that someone decided simply to excise material that failed to advance the plot. (487)

Not only might this habitual cutting of lines - which lasted throughout the $18^{\text {th }}$ and $19^{\text {th }}$ centuries and perhaps influenced the modern film versions - greatly diminish the agency of the women characters in Othello, but it also contributed to the 'caricaturization' of each one. When Emilia and Desdemona had no time to explain themselves on stage, what was left was an archetype; the naïve young girl and the wise old nurse. Most modern editions of Othello, however, include the lines that were excised from the F, and it is up to director discretion whether or not to include them. All of my research and my performance was based upon the expanded Q text. 


\section{Emilia's Epistemological Role}

Perhaps most strongly arguing to her centrality in the story of the play, Emilia represents knowledge in Othello, which could very well be called an epistemological tragedy. Mirroring one of the first tragedies of the Western world - Sophocles' Oedipus the King, which skeptically mocks human attempt to know anything for certain - Othello becomes tragic when the titular character begins to doubt the one thing he should know for certain: Desdemona's fidelity. Even in Shakespeare's source, Cinthio, “the ensign's wife,” is the sole survivor of the incident, and it is she "who knew the facts, narrated these things after [the ensign's] death as I have set them down here” (Hecatommithi, 236).

Emilia is a watcher and a knower, not only is she present and listening to many intimate conversations between Othello and Desdemona, but it is her careful eye which takes up the dropped handkerchief. She is the one who knows everything that is going on, everyone's coming and goings. Consistently, Emilia is the one asked to 'run and tell' what's happened, making her the vehicle of knowledge in the play. Exemplified in 5.1, Iago charges Emilia to "run you to the citadel and tell the Captain what's happened,” positioning Emilia, when she runs into 5.2, as bringing with her all of the knowledge that will define the remaining moments of the play. Ultimately, Emilia holds the knowledge that will undo all of Iago's schemes and lies. Emilia is the one who tells the truth, not just in 5.2, heartbroken and defeated by 'villainy,' but also in 4.2, before Othello commits the murder. Othello comes to Emilia, the reliable source, seeking the truth about Desdemona, “the scene that's never staged in plays that turn on misinformation” (Rutter, 168). Although Othello receives the truth from Emilia, in plain and simple, authoritative terms, "if she be not honest, chaste, and true, there's no man happy," he refuses to believe her (4.2.17-19). Emilia vehemently affirms Desdemona’s honesty when 
questioned, and chastises Othello’s suspicion of her: "remove your thought, it doth abuse your bosom” (4.2.15).

Soon after, without knowing it herself, Emilia reveals Iago’s entire scheme to both Othello and Desdemona, asserting that some “wretch,” some "villainous knave” has "devis'd this slander” against Desdemona (4.2.153-165). Most shockingly, Emilia even figures out Iago’s motive, without ever suspecting her husband, when she says that the knave must have slandered Desdemona’s name "to get some office” (4.2.155). Emilia emerges as the voice of truth in the play, speaking aloud the knowledge that gets lost and muddied by Iago’s whispers. However, Iago’s own plans fail because he lacks the knowledge of his wife’s depth of character.

\section{Dramatic Locus:}

Carol Neely, in her groundbreaking essay “Women and Men in Othello,” which investigates the powerful principles of gender conflict at work in Shakespeare’s text, asserted that Othello’s “central theme is love... Within Othello, it is Emilia who most explicitly speaks to this theme, recognizes the central conflict, and inherits from the heroines of comedy the role of potential mediator. She is dramatically and symbolically the play’s fulcrum” (Neely, 213). Within this statement there are many powerful ideas about Emilia that beg to be analyzed. First of all, is the central theme of Othello love? I would say so - a great tragedy inherent in romantic love is deftly explained in the text of Othello. The things we love the most can be the same things we hurt most violently; why do we destroy the things we hold most dear? It is Iago’s lack of love, empathy, or emotion that motivates his schemes; he is not capable of love: "Iago is cut off by his nature from the feminine principle. He not only scorns 'feminine' qualities [such as pleasure, mercy, and love], but wishes to destroy them in others” (French, 206). As much as 
Othello may be called epistemologically tragic, in that the pursuit of 'true' knowledge and doubt of actually true knowledge causes human suffering, the subject and concern of that knowledge is romantic love.

Dramatically, Emilia drives the plot of the play. While Iago schemes, pours poison in Othello's ear and sets in motion his little violences with Cassio and Roderigo, it is Emilia who oversees the fulfillment of his wishes, without knowing his intent. It is Emilia who convinces Desdemona to plea so wholeheartedly for Cassio; it is Emilia who comes through for Iago by retrieving the handkerchief and delivering it to him, allowing Iago to give Othello his "ocular proof" and solidify that monster jealousy within him; it is Emilia who concludes the play, damning those men around her for their murderous foolishness. Neely acknowledges Emilia's crucial role: "Emilia, stealing the handkerchief, is the catalyst for the play’s crisis; revealing its theft, she is the catalyst for the play's denouement” (Neely, 231).

Symbolically, Emilia serves as a representation of the balanced views of women. In between Bianca and Desdemona, the whore and the paragon, respectively, Emilia is situated as the moderate, ordinary woman. Shakespeare sets up Bianca as the stereotypical woman of loose morals, little virtue; she is the iconic prostitute, following in the wake of the handsome soldier, with an irrational temper to match. Desdemona, in complete opposition, is an untouchable, untaintable ideal of a woman: "indeed perfection," in all things (2.3.29), described at every turn by the men in the play as beautiful and virtuous. Emilia, remarkably not described by men at all in the text (except by Iago in respect to her 'supposed' deeds), falls somewhere in the middle. She takes great offense at being compared with Bianca, and yet she teases Desdemona for her naiveté in thinking that all women must be moral saints. In the terms of Harold Bloom, renowned scholar, Emilia is "no better than she should be" (441). 
By the end of the play, Bianca is condemned by males for her lifestyle, as Iago blames Cassio’s wound and Roderigo’s death on the “fruits of whoring” (5.1.137), and Cassio does nothing to help, leaving her to Iago’s punishment; Desdemona’s perfection is destroyed by male forces, killed by Othello’s madness over his conflicting image of maiden and whore; yet Emilia chooses her end - emerging as a sacrificial symbol. Her death is not defined nor expected by the masculine sphere. When Gratiano exclaims of Iago, “Fie, your sword upon a woman?” (5.2.266) Emilia faces her own death, and accepts it - choosing to speak aloud instead for all women, insisting that while they may be faced with masculine oppression, "it is proper I obey him," they have some power to disrupt the status quo, “...but not now. Perchance Iago, I will ne’er go home” (5.2.233-234). It is not the condemned sinner nor the blessed saint that ends up having this revelatory power, but the ordinary woman, which makes Emilia's sacrifice that much more powerful.

\section{Heroism and Tragedy}

The tragic hero, as defined in Aristotle's poetics, is the character in the tragedy whose suffering, brought about by his own flawed judgment, defines the action of the play and whose fate is worse or more painful than he deserves. In Othello, Othello may be the clearest character to be identified as a tragic hero. He possesses a kind of hubris, possibly implanted in him by Iago, growing angry at the thought of being made a fool of by his wife: “Cuckold me! ... With mine officer!” (4.1.219-221) His noble character, applauded at the beginning of the show, is literally taken from him at the show’s end as Lodovico strips him of property and title. Finally, driven by the pain of his suffering, having realized the depths of his own sins, he takes his own 
life. In this way, he escapes the great tragic pain that Fate has doled out for him, and thus evades the ultimate suffering that defines a tragic hero.

Desdemona has no agency over the tragic events which happen to her. If she had a lapse in judgment, perhaps it was marrying Othello in the first place, or going to bed alone and following Othello’s orders the night of her death. However, it does seem that Othello would have found a way to murder her one way or another anyway.

When we look at Emilia, though, she has all the potential to become that tragic hero. As Penny Gay, a notable feminist Shakespearean scholar, says, "Whereas Desdemona is a pathetic victim of circumstances, it is arguable that Emilia is the truly tragic female figure in this story: a more complex woman, whose death is brought about as much by her own inner conflicts of loyalty as by her psychopathic husband” (1). Emila's judgment is inherently flawed in her love for Iago. She not only delivers to him the instrument of his great deception (the handkerchief), but she chooses loyalty and service to him over her friendship and loyalty to Desdemona because she thinks the item trivial. When Desdemona asks, "Where did I lose that handkerchief, Emilia?" Emilia replies, off the cuff, “Madam, I know not,” not suspecting a trifle to be a cause of real trouble (3.4.23-24). Emilia's hubris resides in the great faith she has in her husband. She never suspects him, although she has all the knowledge that would implicate him, because she refuses to believe it. Even in the final scene, when Othello tells her it was Iago's speech that set him to the murderous deed, Emilia’s reiteration of “My husband?” (5.2.171-186) and her utter disbelief as she implores Iago, "He says thou toldst him his wife was false. I know thou didst not, thou'rt not such a villain. Speak, for my heart is full,” reveals this deep blindness (5.2.209-211). As Aristotle wrote, "A man does not become a hero until he can see the root of his own downfall," Emilia becomes a hero by the end of the play. When she realizes that her actions with the 
handkerchief, her blindness in favor of Iago, resulted in the death of Desdemona and she chooses to speak, revealing herself as much the culprit as Iago: "She give it Cassio? No, alas, I found it, and I did give my husband” (5.2.274-275). This heroic act defines the climax and the denouement of the play, “... Emilia’s heroic victory over Iago is one of Shakespeare’s grandest ironies, and appropriately constitutes the play’s most surprising moment,” (Bloom, 443).

Emilia's suffering at this point far outweighs what she deserves. In return for what she thought to be a trifling indulgence of fancy for her husband, she is responsible for the murder of her best, perhaps only, friend, and has to face the fact that her husband has so used her and betrayed her that she have greatly mistook his fundamental character. Yet, she is condemned to suffer even more as her "heroic intervention," in the final scene is interrupted by Iago, who stabs her, stopping her speech (Bloom, 456). This portion of the scene is even more disturbing and tragic if Emilia is played to love Iago - for not only is she betrayed by him in deed, but the man she loves has just wounded her so gravely that she will bleed to death over the course of the next few lines. For giving a handkerchief to her husband, not even with the intent of letting him keep it, but for having the work “ta'en out,” or copied, this is Emilia’s end (3.3.340).

In the tradition of Friedrich Nietzsche, great tragedy creates a sacred space where humans can witness the terrible truth of reality, given meaning though beauty. Tragedy's project is to affirm the meaning of human existence in the face of life's inherent suffering - an act of human rebellion that makes life more bearable. Seemingly echoing Nietzche’s sentiments in her essay “Counsels of Gall and Grace,” Carole McKewin comments on Emilia’s larger place in the tragedy of Othello, "Emilia's loyalty to her friend... is what remains whole in the debacle of Othello... With the grace of her friendship, with the gall of her indignation, Emilia makes bearable the horrifying waste of innocence and love in Othello. Within her courage, her anger, 
and her revelation is a measure of hope” (129). In this way, Emilia emerges as a truly tragic figure in the text of Othello, but also one with a decided measure of heroism.

\section{Emilia's Age:}

One of the most interesting considerations when conceptualizing Emilia on stage is her age, especially in relation to Desdemona. Many productions cast Emilia as a middle-aged or older woman. Perhaps most notably, when thinking of Othello, the modern psyche turns to ‘classic' versions of Othello such as Welles’ and Olivier’s, which both cast Emilia as an older, nurse-like woman of considerably lower class, visibly marking Emilia's emotional cynicism of marriage and life - she’s obviously been around the block with Iago. Penny Gay argues that, “traditionally," Emilia is performed as "not particularly genteel, blunt (even bawdy) in her speech and by implication in her feelings" and that "her age is usually set at over forty, to contrast her experience of men and the world with the youthful naivety of Desdemona” (2).

This age difference in casting makes the relationship between Desdemona and Emilia maternal in nature, Desdemona a lost child away from home and Emilia the wise older nanny charged with her care. Gay criticizes this kind of 'traditional' casting of Emilia for being “easy choices for actress and director; they permit a generalized reading of the lines which inevitably will fail to do justice to the complexity of such a speech as that at the end of 4.3” (2). I agree; the 'traditional' performance choice may be suitable for certain productions, but it significantly diminishes the power in Emilia's role, fails to serve the intricacy of Emilia's character, and is not directly dictated by the text either in original interpretation or in modern adaptation.

When we deal with the facts presented in the script, Iago states that he has seen "four times seven years," making him 28 years old (1.3.353-354). Thinking about how Shakespeare 
might have envisioned the casting, Iago's wife would be younger than him, as men usually chose a wife a few years younger. According to a survey of English families from working class to royalty during the Elizabethan period, brides married around the age of 18-19 and men around the age of 24; where nobility and royalty tended to marry younger, the working class tended to marry a few years later (Ross, 149). Desdemona is most definitely one of the privileged class, and is considered of a desirable marriageable age, since she already has turned down Roderigo’s ardent suit. Therefore, Desdemona may have been portrayed as a younger bride, possibly 16 or 17, but could also have been a perfectly marriageable 18 or 19. Emilia, an officer's wife, is definitely not as high-rank as Desdemona, but is not particularly lower class either - she has some status. Emilia's social situation would have probably aligned with the average marriage age for women, meaning she married Iago at 18 or 19 years of age.

Since Iago is 28 at the time of Othello, and we assume he got married to Emilia at 24, the average age for grooms, Emilia would be around 22 or 23. Desdemona, if we aim young, is 16, or she could be as old as 19 when she marries Othello. In either case, we are dealing with a relationship between two young women, more akin to a sisterly relationship than a maternal one. While the age gap between a 16 year old and a 22-23 year old woman, not considerable in number of years, is considerable in levels of maturity - Emilia is not nearly old enough to be a mother figure to Desdemona as much as an older sister. Operating under these assumptions, Emilia has only been married for four years, and would still remember vividly what it feels like to be a new bride in a lonely military camp, empathizing deeply with Desdemona's situation.

In our U of L adaptation, set in the modern, vaguely American, military, we are dealing with a specific sub-demographic of the modern populace when looking at appropriate marriage ages. In 2011, the median age of marriage for a female was 27 and for a male 29, in the general 
American population; however, military marriages present a different set of data: "numerous studies have shown that the marriage rate among military service members is much higher than civilians of the same age” (Lundquist, 1). This research documenting married enlisted soldiers asserted that soldiers, on average, married at around 22 years of age, lower than the 24 years of age of the previous study (Lundquist). In the modern military, officers obtain bachelor's degrees before their commissions and enlisted soldiers are primarily high school graduates (Lundquist). Since both Iago and Othello are officers, their expected marriage ages may be slightly higher than those of enlisted soldiers. In addition, Iago is most likely younger than Othello, because Othello has advanced to the position of general.

Iago is documented in the script as age 28, so we can postulate that he married Emilia around the age of 24, after completion of his bachelor's degree and officer training, before deployment. In this case, the modern adaptation of ages align with the Elizabethan precedent, having Iago marry Emilia at 24. Marriage trends since 1970 indicate a tendency for women to marry slightly older men, therefore Emilia would reasonably be 21-23 when she married Iago (Lee). Four years later when the play begins, Iago is 28 and Emilia would be between 25 and 27. I chose to play her as 25 , closer to my own age.

Alternatively, Desdemona was aged from what would have been on the young side, but still acceptable, in the Elizabethan era (16-17), to what would be considered on the young side, but still acceptable, in modernity (20-22). The actress playing Desdemona was 21. In U of L's adaptation, Desdemona and Emilia are both in their twenties, the age difference between them akin to a junior undergraduate student and a graduate student, respectively. The largest reasonable distance in age between them is 7 years, with the possibility of only 3 years between them. 
Through textual deduction, historical analysis, and then modern interpretation, it is evident that Emilia and Desdemona are closer in age than typically assumed. This close age affiliation produces a much more intimate, dynamic relationship between the two women than does a great age gap. Like best friends or sisters, the audience sees two young women share confidences unabashedly, tease each other, and love one another, while revealing their own vulnerabilities and fears. Youthful casting of Emilia evens the field between the two women, none having too much of an advantage of marital knowledge over the other, each discovering and challenging the complications of marriage with the other. While Emilia has a few years of marriage experience, she is roughly in the same situation as Desdemona, fairly new to marriage, still exploring different tactics to please Iago (i.e. the handkerchief). If Emilia is older, her words and care are more maternal, or else completely flippant, and the handkerchief action seems mean spirited rather than a gesture of appeasement to her husband. An older Emilia has been married significantly longer than Desdemona, so she becomes the holder of wifely wisdom, giving Desdemona “well meant but ill-informed” advice and lamenting the sad state of wives (Hopkins, 158). A younger Emilia instead has the freedom to discover her voice and develop her opinions throughout the play, creating a dynamic character.

While these aforementioned criticisms and explications are valuable and important to consider, they fall short inasmuch as they only explicate Emilia's role as evidenced in the text upon careful reading and literary consideration. However, it is not enough for Emilia to be central to Othello only upon second glance and only upon the page - she must be central to the action and the mood of the piece as a production as well. My goal was to make Emilia memorable and central to each audience, many of whom were college students in introductory 
level theatre courses. I had only the two hours of the show to do justice to Emilia's role. I could not rely on a viewer's knowledge of the text or even their complete understanding of the spoken language. My choices needed to be informed both by critical view of the text and by understanding of the world of the play as it was produced by this specific company, the collective story of the particular production, and the fundamental dynamics of theatrical communication.

\section{Previous Emilias:}

Certainly there are many other ways of creating a memorable Emilia. Carol Chillington Rutter was so struck by a particular performance she wanted to “re-read Othello” through the actress' performance choices twelve years after she saw the performance. Rutter devotes a whole chapter in her book, Enter the Body, to analyzing Zoe Wanamaker’s 1989 performance of Emilia in the Royal Shakespeare Company’s production directed by Trevor Nunn (see Appendix A for a picture from this production), examining her expressions, tone of voice, and movement choices for meaning in as much detail as I evaluate my own choices in this paper.

In many ways, Wanamaker’s Emilia, that so affected Rutter, was the antithesis of the Emilia I wished to create. Set in “claustrophobic, class-conscious mid-Victorian” England, Wanamaker was much older than Desdemona, and clearly a watchful, cautious person (Rutter, 149). To this Emilia, the free-spirited, romantic Desdemona was not just a stranger, but completely “different in species” and the two women "had nothing in common” (Rutter, 149). When thrown together by circumstance upon Desdemona's marriage to Othello, Emilia's role became defined by her new 'ward.' Emilia became the governess and Desdemona the girl in 
need of supervision and schooling: "Wanamaker's Emilia was always on guard, on duty, alert to protocol and boundaries, watchful, reserved" (Rutter, 149).

Rutter describes Emilia’s reserved, quiet attitude as presented by Wanamaker as a result of an abusive, controlling, jealous Iago, who was sexually indifferent toward her (played famously by Ian Mckellan). Upon her first appearance in the quay scene, when Iago begins to mock Emilia, Wanamaker's voice is soft, apparently wanting to sink back into her quiet anonymity that had "covered” her previously (Rutter, 150). In this way, Rutter makes clear that the abusive elements of Emilia and Iago's relationship are highlighted in this performance: Emilia’s body language, collapsed shoulders, yet tense back, "every gesture... taut, economical, even repressed," (162) came from a life with a "sadistic husband who needed to humiliate and punish her" (163).

In this performance, there was no love between Iago and Emilia, not even the illusion of it. Emilia existed in a state of fear, of repression and repudiation. Even in 4.3, a close bedchamber scene between Emilia and Desdemona, this Emilia remained distant, staring "stonily away as Desdemona, the battered wife, still declared ... her love” (Rutter, 171), up until the moment Desdemona, almost in tears at her loneliness, cried out "Dost thou think, Emilia, that there be women do abuse their husbands in such gross kind?”

According to Rutter, Emilia’s bitter response, “There be some such, no question,” (4.3. 70-71) sparks an unexpected laugh from both Emilia and Desdemona which "dissolved the strangeness between them” (171), but only momentarily. After Emilia's revelatory, outraged monologue on women’s ‘revenge,’ Desdemona’s dismissal of her advice as “bad,” sends Wanamaker’s Emilia out, the two women “as far apart as ever” (Rutter, 173). 
Wanamaker’s dynamic last scene in 5.2 transformed Emilia the character or real person into Emilia, the symbol of wronged womanhood. Throughout the performance, Wanamaker's Emilia had been beaten down, oppressed, and primarily silent, a time-weathered and fortunehardened being. In 4.2 and 4.3 Wanamaker showed glimpses of outrage, of genuine feeling, but these were again tempered by her steely, tense fear of vulnerability in the face of her husband. Faced with Desdemona’s corpse and Iago’s orders to “charm her tongue,” Rutter explains Wanamaker's momentary freeze before speech as her point of departure. In that moment she decided not to obey her husband, and in that moment, she became free - losing the notion of herself and the distinction between herself and Desdemona. Wanamaker's Emilia, to the great praise of Rutter, was no longer a mere woman, but became a wild, frenetic force, “deeply dangerous," who "would tear down patriarchy with her bare hands" (175).

Wanamaker's older, world-weary, stoic, and repressed Emilia clearly fit the world and vision of Trevor Nunn's production and left an incredibly affecting memory with a notable Shakespearean scholar. However, as is the case with every production, and is part of the magic of theatre, the world of the production can be drastically different, the people who live in those worlds, though saying the same things, can be completely different people. As much as my Emilia would not fit in Trevor Nunn's production, Wanamaker's Emilia would not fit in our production. Deciphering the personality of a character depends as much on setting, audience, time period, and the choices of your fellow actors as it does on story and lines.

In order for Wanamaker's version of Emilia to make sense and be supported by the action on stage, she had to be coupled with Mckellan's distinct version of Iago. The audience had to be made aware of the intense emotional and physical abuse that existed in their relationship to 
understand Emilia's reticence and distance. Gay is less enamored of Wanamaker's performance, noting her age and the actress' relative sad and suffering atmosphere (3).

I have already mentioned notable film productions which so strip Emilia’s part that she becomes a caricature, reinforced by the actresses' portrayals and the production's costuming. In Burge's version featuring Laurence Olivier, Emilia is played by Joyce Redman, many years older than the ingénue Desdemona, with her head wrapped in the fashion of a nurse (Appendix B). In Welles' version, Fay Compton is another older, nurse-like Emilia with hunched shoulders (in Rutter’s words: “a sturdy games mistress”) (148) (Appendix C).

More recently, there have been several notable productions of Othello which have garnered critical praise in the West End. My brief examination, consisting of a random sample of popular productions, is by no means exhaustive or, indeed, representational of contemporary Othello productions, but I do believe they reveal important trends about the casting of Emilia.

The Globe theatre in London produced a version of Othello in 2007 featuring an Emilia, played by Lorraine Burroughs, a young woman with darker skin (Appendix D). Not only did this bring another level of racial complexity to the stage, but this Emilia looked to be the same age as Desdemona, and was dressed in rich brocade, looking just as well-dressed as Desdemona, perhaps even more so. Their relationship was much more sisterly, open; Emilia was allowed to be feisty and willful because of her youth. In reviews of the production, Emilia is granted the title of 'central character:' "You are grateful for the undoubted excellence of the two central women [Emilia and Desdemona]” (London SE-1); "It is an evening of integrity, illuminated by its four excellent central performances [Othello, Iago, Desdemona, and Emilia]” (The Guardian). In addition, Burroughs receives particular praise for her performance: "But Lorraine Burroughs deserves special mention for a clever and convincing night as Aemilia - Iago's strong but 
confused wife (why didn't she guess why he wanted that handkerchief?)” (London SE-1); "Emilia (Lorraine Burroughs), is sensational. Her hysteria in the final scene seems to harvest all the stored pain of the play” (The Guardian).

Also in 2007/8, the Donmar Theatre put on a production of Othello that received great criticism and was hailed by the press (Appendix E). Its star-studded cast (Ewan MacGregor as Iago, Kelly Reilly as Desdemona, and Michelle Fairley as Emilia) received much attention and, while the entire run sold out quickly, tickets were resold on eBay for a record $£ 2000$ (The Guardian). Michelle Fairley, a woman in her forties, widely known now for her work as Catelyn Stark on HBO's series Game of Thrones, was presented in contrast to the young sex icon Kelly Reilly. While Fairley gave a wonderful performance, the overwhelmingly positive reviews of the show largely overlook her role, focusing instead on the strengths and weaknesses of the performances of Desdemona, Othello, and Iago. In the New Yorker, in a review of substantial length, her direct praise is limited to one, parenthetical, sentence: "At the finale, Iago, in the face of his wife's full-throttled outrage at his actions - 'Let heaven and men and devils, let them all, / All, all cry shame against me, yet I'll speak,' Emilia raves—finally kills her to shut her up. (Fairley is astounding in this scene.)" (Majestic).

The National Theatre in London produced a version of Othello in 2013 which featured a hyper-realistic modern military setting (Appendix F). Emilia was cast as visibly older than Desdemona, and was featured as a soldier herself, dressed in camouflage pants and a military issue t-shirt. Implied in this context was Emilia’s “assignment” to Desdemona; it was Emilia’s military duty to watch over the young, civilian Desdemona. This relationship was neither sisterly nor of a mother/daughter kind, but definitely of a master/servant relationship. Emilia worked for Desdemona, creating a profound emotional distance between the two women. Lyndsey Marshal, 
the actress who played Emilia in this version asserted that, “Emilia's an older voice, but she’s trying to be a comforting voice," when the two women have their 'intimate' talk (over beer in lawn chairs) in 4.3. This portrayal of Emilia emphasized her emergence as a feminist despite her abusive relationship with her husband. Reviews scarcely mentioned Emilia, except for one comment in the Financial Times, "Lyndsey Marshal is on very strong form, too, as Emilia, Iago’s wife, a woman who is struggling to make her way in a man’s world.”

Out of these three modern productions, all of which were very popular and received copious criticism, one Emilia stands out. Lorraine Burrough’s portrayal of Emilia as a young, vibrant, sisterly woman garnered the most critical attention and caused her to be named among the central characters of the play in two separate reviews. While both Fairley and Marshal's performances were acknowledged by reviewers to be excellent, they both seem to be shuffled off to the sidelines in favor of praising Desdemona, Iago, and Othello’s performances.

\section{Part II: My Performance}

\section{U of L's Othello:}

U of L’s February 2015 production of Othello was set in a modern, but 'fantastical' world. Ultra-realism was not desired in set or costuming, but hints of the modern world should have been visible throughout the production. For example, the soldiers all wore military jackets, boots, and cargo pants which resembled modern military dress, but their colors and insignia were not associated with real places or ranks. Senators and the Duke dressed in classy modern business wear, but Brabantio’s robe gave an air of fantastic grandeur. The simple, bi-level set reflected a vaguely Mediterranean atmosphere, but did not hold itself to one particular place, and the props all fell into a sort of classical "Shakespeare-land” period. Instead of flashlights, the 
soldiers had lanterns. Instead of military-issue knives, they had elusively eastern-looking short swords. All elements coupled together with an intensely multi-colored lighting design and an intriguing, modern-electronic sound design, thoroughly conveyed the ambiguity of the concept of "modern fantasy."

The show was directed by theatre department assistant professor Daniel Hill, who felt strongly about making the story relevant to a modern, university audience. In an interview conducted by Erica Walsh, communications and marketing professional for the University of Louisville, Hill said, "This play has been produced for more than 400 years and these themes of power, greed, racism and the manipulation behind it are just as prevalent today.” In the same vein, Hill did seek a 'fresh take' on the material, looking to reflect the diversity on our own campus and in our country at large: Othello was played by a first-year graduate student of Malawian and Indian descent, and the rest of the cast was equally diverse. Contrary to what audiences might have expected, our Othello looked 'middle-eastern' rather than 'black,' and was not the only dark-skinned actor in the cast, nor the darkest of all. As Hill put it, "What we're trying to do is look at it from a slightly different lens. What would it look like if Othello's army was representative of the diversity of America's army today, with diverse cultures in higher ranks like general? Our casting for this show celebrates the diversity of our program and updates the look of the typical American production of Othello to represent many people and many races” (Walsh).

This casting inherently took some of the racial pressure and conflict away from the show. While Iago is typically thought of as a deeply racist character, this casting deflected the motivation of his animosity toward reasons other than skin color. Iago's hatred instead grows 
more out of his frustration of being passed over for promotion and the baseless assertion that he's been cuckolded by the Moor - and his intrinsic motiveless maliciousness.

This, of course, had far-reaching consequences for each actor. This particular choice created more emphasis on the dysfunction and tension in Iago and Emilia's relationship, bringing to the forefront of the action the misogyny and degradation evident in Iago's views toward women. It also provides a direct contrast in the relationships between women and men. The most important male relationships in the play are rooted in deception and jealousy. The most important female relationship (for there is really only one), between Emilia and Desdemona, is alternatively rooted in devotion and kindness.

My performance of Emilia served as my undergraduate Senior Honors Thesis, and I was so fortunate to have such a wonderful, supportive cast and crew. In addition, Iago served as third-year MFA candidate Travis Stolp's thesis performance. This had an incredible impact on the mood of the show. The kind of intense focus and thoroughly researched thinking required to complete a creative thesis seemed to 'up the stakes' in every scene we had together. We were both concerned with embodying our own ideas about the characters so that we could exemplify our actions detailed in our papers, but we also had to negotiate the story together. Theatre is an inherently communal act, and Iago and Emilia needed to have lived lives together before the opening of the show, needed to 'match' in some way and not be two completely divided individuals from different worlds.

While I cannot speak for his experience, I used his discoveries of character and his acting choices in the rehearsal room to inform the creation of my Emilia. As a character almost completely defined in terms of her husband, I felt that Iago's attitude toward her would most definitely shape the way she approached him and the way she felt about tolerating his "fancies." 
One of the clearest examples of this cause-and-effect interactivity in our choices was the evolution of the quay scene. Even though I only had two lines, I was determined to make Emilia's presence felt; at the same time, Travis was concerned with establishing his own character and introducing the audience to his scheme with Cassio.

At first, the moment played in a mean fashion. Iago and I came in on stage, an evident distance between us. I paid little attention to him and focused instead on Desdemona and Cassio. When he began to mock me, it was a bitter thing, and I soon felt Emilia slipping into self-pity and embarrassment. We kept toying with the moment, but nothing felt completely right. Finally, I decided that, after we entered the scene and had the initial welcome, I would sidle over to him and take his arm. It was a playful moment, though I saw and felt clearly the tension in Iago when I touched him. We shared a look; I smiled at him, and he gave a subtle, but amused smile back.

With that smile from Travis as Iago to me as Emilia, my whole outlook changed. I felt Emilia yearning for another smile from him, another brief glimpse of acknowledgement and joy, however small. It then became my goal in the scene, and in many others, to make him happy - to see him smile at me once more. We see the deadly implications of this motivation when I choose to give the handkerchief to Iago.

As the scene continued, we both looked to the horizon upon the exclamation of "A sail!" and Iago nudged down to me, pointing it out, even though I could clearly see it. I laughed and nodded, holding on to him, amused at the teasing. After I passed to Cassio for our interlude, laughing and smiling, enjoying his attention, Iago makes a jab at my character. After having this revelation of motivation, instead of becoming upset over his insinuations, I smiled wider, mock gasping and turning to Desdemona in disbelief, turning Iago's mockery into something that felt like an age-old banter between us. When Iago remarks that I "chide with thinking,” I came close 
to him and tugged on his sleeve, smiling and 'chiding' him in good humor - "you have little cause to say so.”

Travis ran with my change in demeanor, and his entire mode of performance of this scene changed - instead of bitterness, he became playful, 'working the crowd' on the quay, performing off of my responses. Together, Iago and Emilia played a little scene of husband-wife bantering before their friends to pass the time until Othello came; the good humor and smiles hiding the smell of calumny that ran underneath. His criticism of me, even when I took it in stride as Emilia, playing with him to please him, served to drive Cassio, Desdemona, and I closer together - we came together to lament Iago’s 'slander,' while he distanced himself metaphorically and literally from our sociable group to share his devious plots with the audience.

\section{Crafting Emilia's Likeability:}

In the words of my former acting professor James Roy Tompkins III, “self-pity on stage never works. If you feel pity for yourself, the audience doesn't have to. And won't." 'Playing the positive' is a basic tenant of acting - it is always more interesting, more engaging to see someone pursuing a goal tenaciously than to see someone giving up or giving in. Audiences engage with active characters because they beget and radiate energy, the audience has something or someone to invest their care in. It is within this realm that the true and effective communicative exchange happens, and leaves the audience member with a lasting impression. It is with this frame of mind that I approached the creation of my Emilia. I wanted to make her as engaging, as interesting and as likeable a character as possible.

I started with the basic notion that Emilia is an inherently good-humored, kind, and generous person. Before Desdemona’s arrival, Emilia was the only 'gentlewoman’ or woman of 
'good-breeding' (Emilia actively excludes Bianca from this set) in the company of the soldiers. She obviously knows them, and is at least friendly with Cassio (exemplified in the arrival to Cyprus scene and in her continued support of Cassio's suit). After Desdemona is placed in their company, Emilia is made lower when she had once been 'top dog.' She is instructed to look after Desdemona, when before she had only herself to worry about. However, Emilia seems to harbor no resentment over this re-assignment, but instead befriends Desdemona, comforting her and sharing gossip with her. Emilia is constantly trying to please or comfort others, primarily through humor. She jokes with Cassio the morning after his brawl, teasing him about his “displeasure,” and assuring him that "all will soon be well." In her one intimate scene with Iago, she uses the handkerchief as a flirtatious bargaining chip, almost teasing with her questioning of him, "What will you give me...?” (3.3.349) With Desdemona, she tries to comfort her with words of empathy, of shared experience with the attitudes of men: "Tis not a year or two that shows us a man...” (3.4.120). In 4.3 her humor comes out unabashedly as she talks about deeds better done “i'th dark” and Lodovico’s good looks, despite the tragic heaviness that has fallen over both women (4.3.40-76).

I chose to highlight this good-humor, without tipping over into bawdiness or bluntness. I entered almost every scene with a smile, if not laughter. In my first scene, when Iago begins to mock me, I chose to engage Iago in a banter, criticizing him as much as he criticized me, even with my few lines. In this way, we established a routine of mocking bantering that seemed natural, if a little rude, between the two of us. In this moment, Iago and I are both smiling with each other, even though I am the butt of the joke, and I am content with that. In the end, both Cassio and Desdemona side with me, criticizing Iago for his rudeness. At the end of the scene, I established a friendly connection with both Cassio and Montano and they both took my arms as 
we exited the stage, expressions and murmured tones of recognition giving the impression that they were glad to see me again, a reunion of old friends.

In developing a relationship with Desdemona, along with the sisterly connection that came along with playing both Emilia and Desdemona as young women in their twenties, I wanted us to come across as fast friends. After all, as evaluated by McKewin, in the entirety of the Shakespearean canon, "only in Othello, with Emilia and Desdemona, are we allowed a feminine friendship of considerable dimension, and a dramatic moment long enough to reveal that relationship. ... Desdemona and Emilia reveal a feminine friendship that is affectionate and frank, generous and nurturing” (128). I sought to elevate this friendship to the central and important role it deserved. When speaking with Desdemona, we were always close, laughing and smiling with one another. Equally, we reached out to each other for comfort and affirmation, and we both defended one another in the face of men. She did not tolerate Iago's 'slanders' of me on the quay in my first scene when she shouted out, "Fie upon thee, slanderer” (2.1.126) and I chose to step in front of her, shielding her from a vicious, crazed Othello when he called her "that cunning whore of Venice” (4.2.104).

While Emilia’s practical observations, “'tis not a year or two shows us a man,” (3.4.120) and "[Jealousy] is a monster begot on itself, born on itself," (3.4.180) may seem the fruit of worldly wisdom or cynicism devoid of joy, they are merely the products of an astute mind, coupled with a growing suspicion and suspense regarding her husband. After all, even though Emilia is an "expert at noting and analyzing jealousy," she "seems untouched by it herself. Even her argument for the single standard is good natured; it contains little hatred of men and no personal animosity toward Iago” (Neely, 224). She does not hate men in general, nor does she 
hate her husband Iago; there is nothing in the text that would directly support that interpretation. Therefore, my Emilia became an object of cheer, of humor, cleverness and loyalty. Iago, disgusted by the joy or success of others, must hate laughter, even as he uses it as a tool for his own gain. Bloom notes his "saturnine hilarity" as the only humor in the play, but that Iago is deeply afraid of laughter himself, "only humor could defend against Iago” (438). Perhaps this hatred is driven by his own disgust or frustration about thinking himself an object of ridicule, laughter (cuckolded, passed over for promotion). In this way, Iago instills in Othello his own paranoia, insisting that others are laughing at him behind his back, being made a fool of by his own officers. So how would it be possible that Iago would end up marrying such an affable woman? In one sense, Iago and Emilia are both charming characters - with a marked difference in their intents - but Iago may have seen Emilia’s sociability as useful. Or, Iago may have once been attracted to joy or laughter in her, wanting to possess it for himself, but is now repulsed by her cheer, seeing it as reflective of his own sense of ridicule.

In another fashion, if Emilia is played positively, with genuineness, charisma, and humor, she becomes Iago’s “sustained counterpoint” (Hopkins, 157). Iago becomes that much more dastardly when he is placed next to a likable and good Emilia. In this way, she becomes the ultimate source of dramatic irony, the genuine and loyal friend and wife who undoes the master schemer Iago's plots, because he never suspects that his wife would stand against him in such a strong way (even though he readily suspects her of infidelity). In the end, it is only through Emilia’s deep loyalty and friendship, in direct opposition to Iago's deception, that Iago is destroyed. Yet, on the outside, they are both characters of affability. Iago gives off the illusion of friendship, loyalty, and honesty (how many times does the audience hear about “honest Iago?”), and Emilia sincerely embodies these values. 
Her openness, sincerity, and desire to please end up revealing a great vulnerability, one that is exploited thoroughly in the final scene, much to the surprise of the audience and Iago.

Bloom describes the final scene as the greatest dramatic irony in Shakespeare's works:

We are surprised, but Iago is shocked; indeed it is his first reversal since being passed over for Cassio. That Emilia should lose her worldly wisdom, and become as free as the north wind, was the only eventuality that Iago could not foresee. And his failure to encompass his wife's best aspect - her love and pride in Desdemona - is the one lapse for which he cannot forgive himself. That is the true undersong of the last lines he ever will allow himself to utter, and which are directed as much to us as to Othello or to Cassio: 'Demand me nothing. What you know, you know./From this time forth I never will speak word.' What is it that we know, beyond what Othello and Cassio know? Shakespeare's superb dramatic irony transcends even that question into the subtler matter of allowing us to know something about Iago that the ancient, despite his genius, is incapable of knowing. Iago is outraged that he could not anticipate, by dramatic imagination, his wife's outrage that Desdemona should be not only murdered but perhaps permanently defamed. The aesthete's web has all of war's gamelike-magic, but no place in it for Emilia's honest indignation. Where he out to have been at his most discerning -within his marriage- Iago is blank and blind. The superb psychologist who unseamed Othello, and who deftly manipulated Desdemona, Cassio, Roderigo, and all others, angrily falls into the fate he arranged for his prime victim, the Moor, and becomes another wife murderer. He has, at last, set fire to himself. (444)

Additionally, in criticism and a strictly textual analysis, Emilia's death is completely ignored by Othello: “Emilia’s death, though it reenacts Desdemona’s is a mere parenthesis in his search, scarcely noticed by [Othello]” (233). However, in our production, without any prompting or exchange of my goals in my thesis, the way this event played out illustrated that my performance of Emilia had affected the other players on the stage in ways unanticipated by the 'traditional' performance of Emilia or in the aforementioned kind of critical scholarship. In our production, Emilia's death shocked Othello so much that he froze in his attempt to kill Iago and fell to his knees, hands outstretched to catch the doomed Emilia, who he had threatened (albeit 
weakly, with no desire to kill her) just before. In fact, he honors Emilia's last monologue, silently holding both her and Desdemona while she dies. When Emilia's breath catches on the willow song, Othello moans and begins to cry. I was told by the actor playing Othello that it was the moment that our eyes caught over Desdemona's body, when he saw the absolute pain in my eyes, the depth of the betrayal, that he as an actor really began to feel the depth of the tragedy in that last scene.

I faced a particular challenge in crafting Emilia as a likeable character when it came to my interactions with Bianca, played by a very talented $2^{\text {nd }}$ year graduate student, Candice Handy. Her performance was so funny and dynamic, audiences immediately liked Bianca, despite her short stage time. Yet, in 5.1, Emilia insults her (5.2.142), and in our production, slaps her. When Iago blames Bianca for Cassio’s wound: “this is the fruit of whoring,” (5.2.137) I am with my husband in his condemnation of her; in fact this moment is one of the tenderest moments between Iago and I in the play. He explains the situation to me when I ask (rare enough), then he goes on to request that I carry important information to the general, trusting me to get it to the citadel (I am, of course, unaware of what he's sending me into). But, when Bianca says that Cassio was with her that night, I am livid that my friend has been hurt and still operating under the assumption that Bianca is somehow responsible, that's all the information I have from Iago. When I call her out as a "strumpet,” I mean to belittle her, to condemn her for her shamelessness that has caused this suffering; to prove to Iago, standing nearby, that I do not condone sleeping around, that I am not at all sympathetic to whores; more than that - I am not one.

Bianca comes back at me, strongly, claiming defiantly that she is "No strumpet, but as life as good as you that thus abuse me!” My challenge laid in that I didn't want to alienate the audience by being antagonistic to a likeable, funny character. My thought process as Emilia 
incorporates my fury at being, essentially, called a whore again. It was bearable in the quay scene because it was subtle underneath good humor amongst friends, and his criticism applied more generally to woman-kind as a whole (Travis leaned on one of the senators to illustrate this). But Iago's suspicion of me continues to cut me deep, every time it's mentioned - which Iago does often enough. I doubt he's called me whore to my face - my fury at Desdemona being called the word outright shows this. But his veiled insinuations are worse. He calls me "a foolish wife," "a common thing," "a fool.” His sneering degradation of me, coupled with his jealousy, both makes me long for his approval, and worms its way into my mind, making me doubt my own worthiness, my own value. Bianca's outburst that she is as good as me, when she is obviously a prostitute, the thing I am so often accused of, makes me snap - I can't take the condemnation from another source, in front of my husband. I am not a whore!

However, it was very difficult to make sure this entire, complicated thought process came out in the two lines I had. I might have damaged my character's likeability with some audience members by coming off too nasty in this moment.

\section{Defining Dynamic Character Arc:}

Another crucial tenant of dramatic action which I used to inform my character creation was the fact that change is always more interesting than stagnancy. A character who undergoes a change from who they were at the beginning of the play is infinitely more appealing than a character who remains the same from beginning until end. Theatre, as is life, is made up of struggles, conflicts, and changes - it's what moves the story along. A cynic from the start is not as interesting or engaging as witnessing the struggle of a character, the fall, the birth of disillusionment. 
Performances of Emilia that start the character off world-weary, knowledgeable, or cynical greatly reduce the arc of character transformation that is available to Emilia. If she is already cynical of marriage, so beaten down by Iago that she has succumbed to a loveless life, her ultimate sacrifice in the final scene seems like she's giving up - she knew it was bound to happen one day, why not now? However, if Emilia is hopeful, optimistic, and most importantly, still in love with her husband, she has a much greater distance to fall before that final scene - a much more interesting progression to watch, and a much more affecting and engrossing set of actions.

Even critics who note Emilia's importance in Shakespeare's text do not seem to take into account that her character has the possibility for change, "Emilia's function and attitudes do change, however, though her character perhaps does not. She moves from tolerating men's fancies to exploding them and from prudent acceptance to courageous repudiation. She ceases to function as a reconciler of the views of the men and the women, and the separation between them becomes absolute” (Neely, 234). But in this delineation of her character, Emilia is reduced to mere function - she is no longer a woman but a symbol, the dramatic trope representing the distance between men and women. Like Zoe Wanamaker’s performance, Emilia ceases to be a character in the last scene if she is not allowed a dynamic character arc, she must become a symbol of all women, something larger than truth. Similarly, Marilyn French, author of Shakespeare's Division of Experience, which reads Shakespeare's texts looking for gendered principles, designates Emilia as "spokesperson for women in the play” and calls her "worldly," "resigned," and "cynical,” her speech in 4.3 to Desdemona a "sermon” (217). It seems that in the world of scholarship, Emilia can be a mouthpiece for women's rights only if she adopts the bitterness that comes with knowing and accepting the inevitability of patriarchy, and she can 
only become that ‘spokesperson' after sacrificing her personal self-hood to become a symbolic martyr in the final scene. However, I sought to find an Emilia who could be both a real person and speak to the plight of women - which I think is both more truthful to reality and more interesting to watch. The audience discovers the great iniquities and double standards inherent in society with Emilia as she struggles with the situations she finds herself in; they are not preached at by an all knowing figurehead.

In the same vein, performances that begin the play with a deep, irreconcilable divide between Iago and Emilia shorten the dramatic distance the relationship has to fall, to suffer, to change. It is Emilia who is most duped by Iago's schemes, who thinks her husband may be "wayward" and at times a little unfeeling, but is essentially a good person. After all, when Iago sends Emilia out to speak to Cassio, she “attributes to Iago her own capacity for empathy,” assuming that he is capable of feeling sorry for Cassio (Neely, 228). When Emilia decides to have the handkerchief copied for Iago, it is much more affecting and tragic if it is her attempt to please him, to rekindle some lost romance, than if it is done out of fear or blind servitude. Iago's betrayal is deeper, more profound, more tragic if Emilia loves him still - even more so if she loves him even as he kills her. It is the absolute breaking of her heart that occurs in the last scene, as she has everything she loves in the world ripped from her, and is betrayed in the deepest fashion by the man she trusted and loved the most.

I used this idea to fuel the power of the last scene. The spatial arrangement of the set made it necessary for all characters entering in 5.2 to move into the tunnel under the top platform during the scene change from 5.1. It was a somewhat tight fit, and it meant that before I entered as Emilia for that final scene each night, the actor playing Iago was literally at my back. Standing in silence, listening to Othello and Desdemona's conversation, and waiting for my cue from the 
assistant stage manager in the wings to enter, I meditated on his energy behind me, and everything that meant for Emilia. Using his physical presence and proximity, by thinking through all the reasons Emilia loved him - what it must have been like before his jealousy for her to say yes to him - what it felt like in those golden moments to have him smile at her - what closeness like this might have meant to her. As Emilia, the thoughts in my head run the gamut from, "Poor Desdemona, I have to tell her that goofy suitor of hers, Roderigo, is dead" to "I hope Cassio is okay!” to “I can’t wait to tell Desdemona about everything that's happened,” to one that I lingered on for the longest, “Iago - I know we're in a rough spot now, but we'll get through this. When I see him again tonight we'll make things better...” And then I entered.

One of the scenes that challenged me the most, but was perhaps the most important in emphasizing Emilia’s change in character was the close, intimate scene between Emilia and Desdemona in 4.3, commonly known as the unpinning scene. Throughout the rehearsal process I felt like I was not getting the spontaneity necessary for this scene. I needed to remember that these words were coming to Emilia, she doesn't have them stored in her head as a manifesto, unlike how she may have been played stereotypically. That's the difference in my performance. Her spirit emerges as she discovers it through suffering. I needed to make sure that every line was new to me in the moment, as I thought it. I also felt in some rehearsals like I was losing some of the fun in this scene - maybe because I was pushing too hard to make it "great," and probably because I wasn’t focusing clearly enough on my objective: to cheer Desdemona.

I've done this piece for so long as an audition monologue, I had the rhythm and pitch of my usual reading of it ingrained in my body. It was so hard to shake loose of that and approach it new every night. In order to liven the scene up, to participate in the discovery of the words, and to remember my objective - I practiced the scene several times playing the opposite of each line. 
Instead of going up in inflection on a line I tried going down. Instead of doing a specific action on a line, I tried doing the opposite physical action. Instead of joking on one line, I joked on another. This playing of opposites in the scene helped me open up a new realm of possibility within the scene and within my ending monologue.

\section{External Challenges:}

In the $\mathrm{U}$ of $\mathrm{L}$ theatre department, costume designs are decided and agreed upon in advance of the beginning of rehearsal. In this production of Othello, the designs were agreed upon even further in advance because the rehearsal period was split over both semesters, divided by the holiday break. I had begun only preliminary character work and not come to any conclusions about my presentation of Emilia when sketches were agreed upon, and in any case, actors, especially in a University setting, have little autonomy over the look of their own characters. Because of this, the costume design for Emilia reflected some of the very stereotypes of her character that I was trying to break in my performance. The costume designer had very firm ideas that Emilia was the "most conservative" of the women in the play, that she was “older” and “wiser.” Emilia’s look, therefore, reflected more of the 'wise old aunt' than I wished, making her seem tired and quite a bit older than Desdemona. However, I tried to combat the immediate look of my character by infusing my performance with energy and excitement, trying my best to establish a sisterly, gossipy rapport with Desdemona to diffuse the older look.

An additional challenge was the particulars of the set construction. The set was a very tall, multilevel construction with several on and off stage staircases. Handrails could not bear weight and they could not be used as any support or precaution. There was also a complete lack of handrails on the back portion of the set, making my many ascents and descents in heels 
particularly scary. The tread width on the stairs was also slightly smaller than normal, my size 8 foot only barely fitting on it. The trepidation I felt about ascending and descending the set affected my movement speed, transforming entrances that I had been running in on into slower, careful entrances, which changed the level and type of energy I could bring into the scene.

Another, perhaps very hindering, challenge of this production was the scenic arrangement of the final scene. Both the bed and the doors were very large scenic elements in this scene which pushed the action of the scene further downstage. In rehearsal, we were often told we had 'plenty of room' and so practiced with a much more spatially understandable arrangement than what ended up being portrayed in performance. The scene was very crowded, and at many points I felt other characters having to 'squeeze by' or step over my corpse. The blocking and scenic arrangement also had the effect of backing me into the corner of the stage during the entirety of 5.2, where I was not scene by the majority of patrons seated house left. Iago's stabbing of me also happened in this upstage, drastically stage right portion of the stage, muddying the action and perhaps diminishing the power of the scene.

\section{Audience Response:}

Of course, there is a challenge of quantifiably identifying success or failure of this project; theatre is always subject to audience interpretation, and my project is no exception. How is it possible to know if an audience received the message I wished to portray with my performance? How do I know if audiences ‘remembered’ Emilia, or took something away about this Othello that they hadn't thought of before that was directly influenced by my performance? I look here at admittedly qualitative and subjective sources of data to answer this question, because, while they may be open to interpretation, I believe they provide the most direct link to 
audience reception. I look here at critical response, my perception of audience response during the show and bows, and unsolicited comments from audience members after the show.

On opening night, our Othello received a review from ArtsLouisville.com, written by Keith Waits. He gave the show a mostly positive review, but noted that "during the first act there was a general resistance to energy that may have just been opening night jitters, because after intermission the production woke up and got down to business. An air of menace made itself known and there were several riveting passages as Iago's machinations yield their deadly results." His comments on the acting in the show were limited to one paragraph out of seven, noting that Iago was "less diabolical than usual” and that Othello’s performance was “darker, edgier," than usually expected. He then moves on to Emilia and Desdemona: "Megan Kubac is a fine, if slightly underdeveloped Desdemona, while Megg Ward does strong work as Emilia, proving crucial to that extended final scene.”

His direct comparison of the performance of Emilia and Desdemona highlights the perceived centrality of both characters, and in his wording, my work as Emilia came out strong enough to capture his attention and prove "crucial.” Especially in a review that focuses more on overarching social implications inherent in our casting of the show and the technical elements than the acting, this solid praise of my performance of Emilia stands out as particularly important.

Each night, I kept a record of audible and felt responses I heard from the audience during the performance. I was pleased to hear various women's voices during the unpinning scene in response to some of my lines. I heard several sounds of agreement and approving laughter. Specific lines that really worked and received audience response sounds were: "might do it as well in the dark" and "I do think it is their husband's faults..." There was a particular line that 
elicited a response I noticed in performance that I hadn't noticed in rehearsal, the line about "tis' not a year or two shows us a man/ they are all but stomachs and we all but food/ they eat us hungerly/ and when they are full they belch us” (3.4.120-4). On opening night the line elicited a few scoffs and chuckles, and I realized the word belch is inherently comical in modern speech, and I would be treading a thin line with the speech. It's a funny word to us now, but the speech is serious, and the moment in Emilia's character transition is important. I wanted to embrace the comedic impact of the line, but also make Emilia’s struggle clear. I ended up changing my reading of the line to embrace the guttural, base nature of the word 'belch.' Instead of embarrassed giggling the next night, I heard heard several scoffs of acknowledgement, which I felt was a better response to the line. I also heard several gasps and audible exhales of surprise when Iago stabbed me in the final scene each night. Often I could hear sniffling in my ending monologue, which I took to mean that the overarching atmosphere of tragedy had succeeded in our show, and that I had been an integral part of creating that tragedy.

The setup of bows also helped to establish Emilia's centrality in our production, and from the responses I felt from the audience each night, I feel like they understood and took with them a particularly strong portrait of Emilia's place in Othello that they might not have understood before. The last four bows of the large company were Emilia, Desdemona, Iago, and Othello, respectively. These four bows were directly distinguished from the rest of the bows because they included a visible rising from the death bed, on which Othello, Desdemona, and I remained until we came forward for our individual bows. I was the first to rise from the bed, and every night I received an overwhelmingly positive and loud reception from the audience. Often, I received the loudest calls from the audience out of the company. This may have perhaps been because I was the first of the 'central' characters to rise from the bed and take bows, but I attribute the calls and 
hoots - beyond the scope of normal, polite clapping - that I received to be a sure sign of good audience reception for Emilia.

I also received several unsolicited comments from audience members, many whom I didn’t know, commenting on my strong performance. Several of them, to my great satisfaction, remarked along the lines of “I didn’t know Emilia was such a big role!” and “Emilia was such a great character!” and “I love Emilia!” Particularly, one of the costume crew asked me after a performance, who told me she had trouble understanding the plot of the play, "Can I ask you why Iago hates Emilia so much? She’s seems like such a nice person - she doesn't deserve to be treated like that." To which I responded, "Well, he thinks she’s cheated on him. And in our production, Emilia does seem to be friends with everyone, but Iago is always on the outside.” The costume crewperson responded, "Right, man... Emilia really does have the saddest ending." This comment, a product of an unsolicited conversation with a nightly viewer, who admittedly didn't understand all the nuances of the language or plot of the show, really made me feel like I'd succeeded in elevating Emilia's role in Othello.

As I have mentioned, it is quite difficult to measure the success of this project, as I am inherently a biased party on the collection of audience response data, however I am also one of the only people who can speak to that physical, felt audience response from the stage. Based on this data, I do feel like the project was a success.

\section{Concluding Remarks:}

I have realized it can be quite a challenge to undertake a project of this kind as a creative artist. Sometimes too much research can be a hindrance to authentic creation. I approached the role having studied past Emilias and having read several critical interpretations of the role, 
however I had to find the path that best allowed me as the modern artist to communicate the story to my particular audience in the particular world that was set up with the ensemble of this production of Othello. There was a constant challenge of being too bogged down in cerebral notions to notice or interact truthfully with the action on stage.

Ultimately, I think my research and exploration only added to my performance of Emilia. I knew what stereotypes I was acting against, and what kinds of responses I wanted to elicit, so my goals were very clear. I also had the support of a wonderful creative team, cast and crew. In conclusion, I believe this sort of combination of creative practice and scholarly research is exactly the kind of work necessary for modern theatre artists. In my studies as an undergraduate, there has always seemed to be a divide between theatre scholarship and theatre production. The scholarship was concerned with theory and historical analysis, and the production side with making actual, live theatre. However, my project attempted to combine the two through applied scholarship in performance, to create a lively Emilia who redefined her 'traditional,' monochromatic role in the popular psyche.

This project represents an exercise in the creation of thoughtful theatre. Here I developed and performed an Emilia that was approachable yet dynamic, challenging yet entertaining, leaving the audience with a visceral memory of a woman who was never tragic in life, but died in a tragically heroic fashion. Emilia’s role can be one of caricature and one-dimensional performance, or she can represent the multi-faceted, complicated existence of a real woman, without losing herself to support an ideology. Careful acting choices such as mine can develop an Emilia who emerges from the darkness of forgotten characters and bawdy servants and allow her to live amongst the light of well-known and well-loved heroines, receiving the recognition and respect she deserved all along. 


\section{Appendix}

A. Zoe Wanamaker as Emilia in Trevor Nunn’s RSC Production in 1989

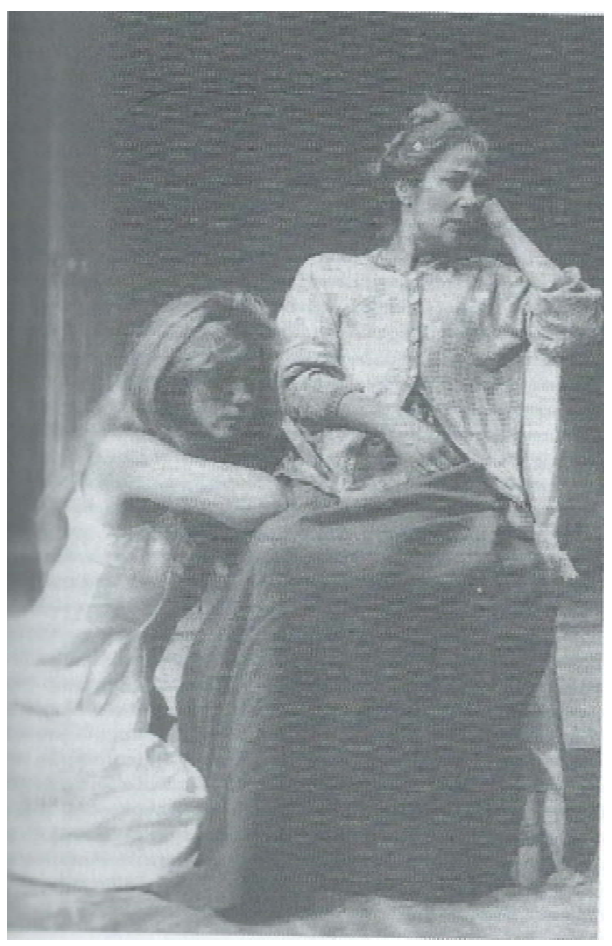

Emilia and Desdemona in 4.3

Rutter, Carol Chillington. Enter the Body: Women and Representation on Shakespeare's Stage. New York: Routledge, 2007. pp. 172. Print.

B. Joyce Redman as Emilia in Burge's Othello

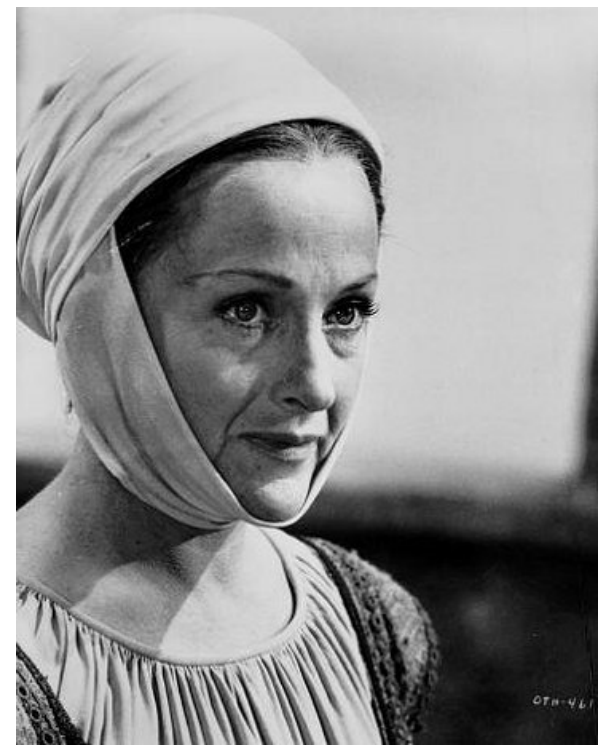

Burge, Stuart. Joyce Redman. Digital image. Television Haven Forum. 1 Jan. 1965. Web. 
C. Fay Compton as Emilia in Welles' Othello

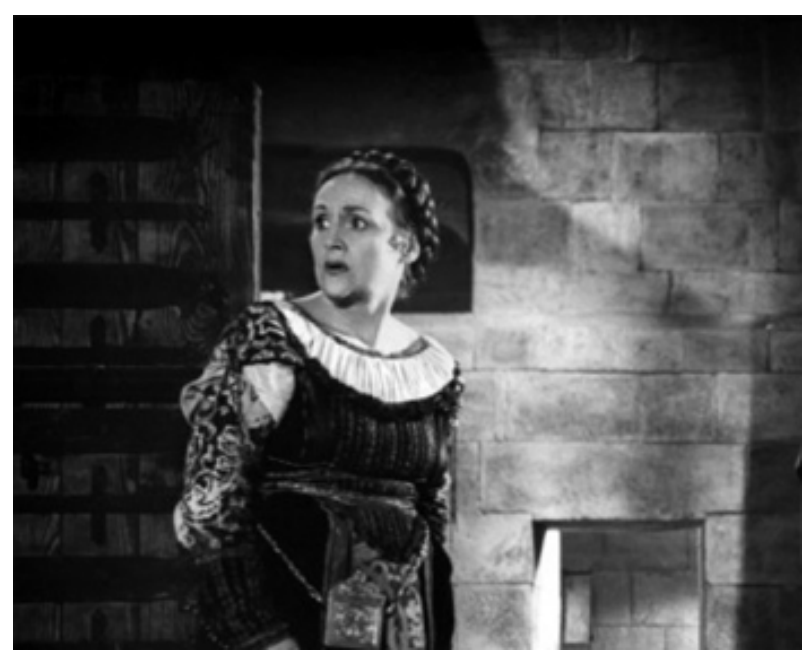

Welles, Orson. Othello 1952. Digital image. Orson Welles: A Retrospective. 1 Jan. 1952. Web.

D. Globe Theatre 2007 Othello



Othello Curtain Call. Digital image. Wooler. 1 Jan. 2007. Web. 


\section{E. Donmar Theatre 2007/8 Production}

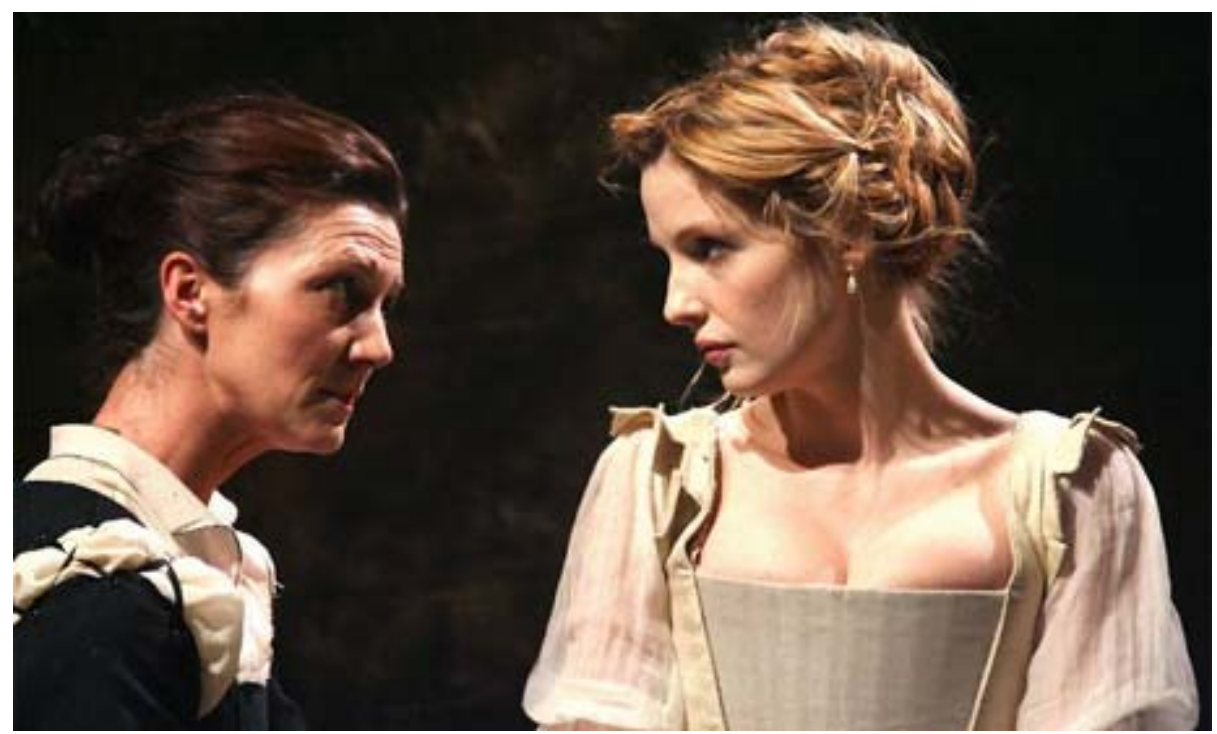

Desdemona and Emilia in 4.3

Bradshaw, Peter. "The Donmar's Othello Should Be a Movie." The Guardian. 5 Dec. 2007. Guardian News and Media. Web. 4 Jan. 2015.

F. National Theatre 2013 Production

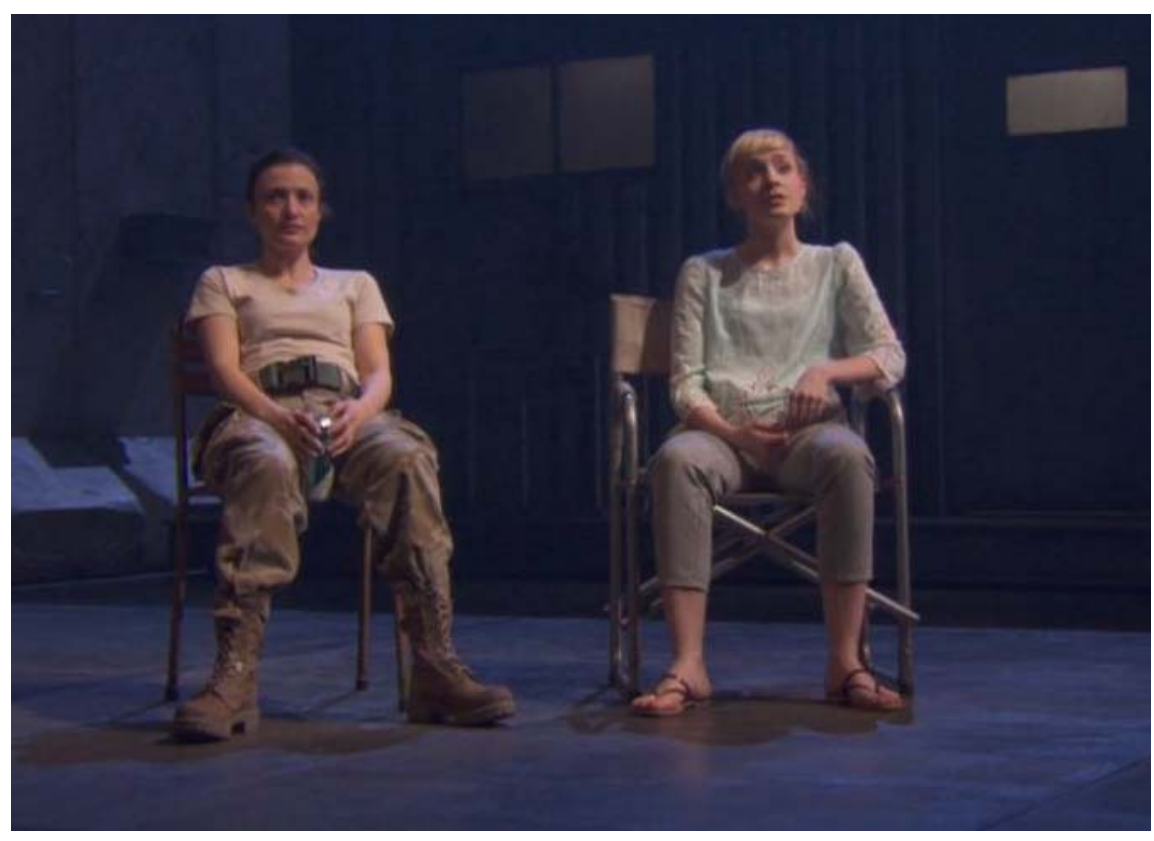

Desdemona and Emilia in 4.3

Desdemona and Emilia. Digital image. National Theatre. 1 Jan. 2013. Web. 


\section{Bibliography}

Bloom, Harold. Shakespeare: The Invention of the Human. New York: Riverhead Books, 1998. Print.

Bradley, A. C. "Othello” and "Notes." Shakespearean Tragedy; Lectures on Hamlet and Othello. 2nd ed. London: Macmillan, 1922. Print.

Bradshaw, Peter. "The Donmar's Othello Should Be a Movie." The Guardian. 5 Dec. 2007. Guardian News and Media. Web. 4 Jan. 2015.

Carlson, D. L., “Deviations From Desired Age at Marriage: Mental Health Differences Across Marital Status.” Journal of Marriage and Family, 74 (2012): 743-758.

"De Gli Hecatommithi." The Sources of Ten Shakespearean Plays. Ed. Alice Griffin. New York: T.Y. Crowell, 1966. 227-236. Print.

Dusinberre, Juliet. Shakespeare and the Nature of Women. London: Macmillan, 1975. Print.

French, Marilyn. Shakespeare's Division of Experience. New York: Summit, 1981. Print.

Gardner, Helen. "Othello: A Retrospect, 1900-67." Shakespeare Surveys 21 (1968): 1-11. Print

Gay, Penny. "Emilia Speaks Her Mind: Othello, IV. iii, 82-99." Sydney Studies in English 24 (2008). Print.

Hopkins, Lisa. The Shakespearean Marriage: Merry Wives and Heavy Husbands. New York: St. Martin's Press, 1998. Print.

Kellaway, Kate. "A Desdemona to Die for." The Guardian 27 May 2007. Guardian News and Media. Web. 1 Jan. 2015.

Lee, Gary R., and Krista K. Payne. "Changing Marriage Patterns Since 1970: What's Going On, And Why?." Journal of Comparative Family Studies 41.4 (2010): 537-555. 
Lundquist, J. and Xu, Z., "Reinstitutionalizing Families: Life Course Policy and Marriage in the Military.” Journal of Marriage and Family, 76 (2014): 1063-1081.

Marshall, Lyndsey and Olivia Vinall. “Othello - Emilia and Desdemona.” Youtube. National Theatre Discover. 29 July 2013. Web. 1 Jan. 2015.

Marshall, Rob. "Othello at Shakespeare’s Globe." London SE1. Bankside Press, 29 May 2007. Web. 6 Jan. 2015.

McKewin, Carole. "Counsels of Gall and Grace: Intimate Conversations between Women in Shakespeare’s Plays” The Woman’s Part. Ed. Carolyn Ruth Swift Lenz, Gale Greene, and Carol Thomas Neely. Chicago: University of Illinois Press, 1980. 117-132. Print.

Neely, Carol Thomas. "Women and Men in Othello: "What should such a fool/Do with so good a woman.”” The Woman’s Part. Ed. Carolyn Ruth Swift Lenz, Gale Greene, and Carol Thomas Neely. Chicago: University of Illinois Press, 1980. 211-239. Print.

Nietzsche, Friedrich. "The Birth of Tragedy." Continental Aesthetics: Romanticism to Postmodernism: An Anthology. By Richard Kearney. Malden, MA: Blackwell, 2001. N. pag. Print.

Ross, Emily. "Ripe to Be a Bride? Marriage Age in Romeo and Juliet." CJPSCS/JJPC (総合政策 研究) 19 (2011): 145-159.

Rutter, Carol Chillington. Enter the Body: Women and Representation on Shakespeare's Stage. New York: Routledge, 2007. Print.

Sexton, Joyce Hengerer. The Slandered Woman in Shakespeare. B.C., Canada: University of Victoria, 1978. Print.

Shakespeare, William. Othello. Ed. M. R. Ridley. New Arden Edition. London: Metheun;, 1962. Print. 
Shuttleworth, Ian. "Othello, National Theatre (Olivier), London - Review." Financial Times 24 Apr. 2013. Financial Times Ltd. Web. 1 Jan. 2015.

Stage Beauty. Perf. Billy Crudup, Claire Danes. Artisan Entertainment :, 2005. DVD.

Waits, Keith. "The Challenge of Today's Othello." ArtsLouisville Reviews. ArtsLouisville, 5 Feb. 2015. Web. 28 Feb. 2015.

Walker, Tim. "Othello, at National Theatre." The Telegraph 26 Apr. 2013. Telegraph Media Group Ltd. Web. 1 Jan. 2015.

Walen, Denise A. "Unpinning Desdemona." Shakespeare Quarterly 58.4 (2007): 487-508.

Walsh, Erica. "UofL Taking Fresh Look at 'Othello"' UofL Theatre Arts Department. University of Louisville, 26 Jan. 2015. Web. 2 Feb. 2015. 